Original Investigation

\title{
Food choice of Eurasian red squirrels and concentrations of anti-predatory secondary compounds
}

\author{
Federico M. Rubino ${ }^{\mathrm{b}}$, Alessio Martinoli ${ }^{\mathrm{a}}$, Marco Pitton ${ }^{\mathrm{c}}$, Daniela Di Fabio ${ }^{\mathrm{c}}$, Enrico Caruso ${ }^{\mathrm{a}}$, Stefano Banfi $^{\mathrm{a}}$ \\ , Guido Tosi ${ }^{\mathrm{a}}$, Lucas A. Wauters ${ }^{\mathrm{a}, *}$, Adriano Martinoli ${ }^{\mathrm{a}}$ \\ a Dipartimento di Scienze Biomediche, Informatiche e della Comunicazione, Università degli Studi dell'Insubria, Via J.H.Dunant 3, I-21100 Varese, Italy

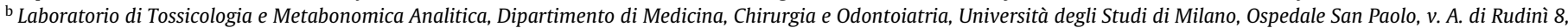 \\ Milano, Italy \\ ${ }^{c}$ Laboratorio di Tossicologia e Metabonomica Analitica, Dipartimento di Medicina del Lavoro, Università degli Studi di Milano, Ospedale San Paolo, v. A. di Rudinì 8, Milano, Italy
}

\section{A R T I C L E I N F O}

\section{Article history:}

Received 7 October 2011

Accepted 17 January 2012

\section{Keywords:}

Abies alba

Conifer seeds

Monoterpenes

Picea abies

Sciurus vulgaris

Tannins

\begin{abstract}
A B S T R A C T
Secondary metabolites (SMs) are organic compounds of low molecular mass that represent a vast chemical diversity. In plants, one of their preeminent roles is their repellent activity against predators. The Eurasian red squirrels (Sciurus vulgaris) is one of the most important predators of conifer tree seeds in boreal and alpine forests in Europe. Its population dynamics and space use are strongly affected by the size of Norway spruce (Picea abies) seed-crops, but not by silver fir (Abies alba) seed-crops. Moreover, squirrel heavily feed on spruce seeds but tend to avoid fir seeds, although the latter has a higher seed-energy content per cone. We tested the hypothesis that a higher concentration of some SMs in fir than in spruce seeds and/or cone scales, the protective tissue of seeds, was related with squirrel feeding preferences. We determined terpene concentrations in the cyclohexane extract of seeds and scales by gas-chromatography-electron ionisation mass-spectrometry (GC/EI-MS), and measured the protein precipitation activity of tannin contained in spruce and fir seeds and scales. Of the nearly 300 separated chemical entities, only limonene, $\alpha$ - and $\beta$-pinene and myrcene occurred in all samples and their levels accounted for $80 \%$ or more of all cyclohexane-extractable materials of fir and for less than $50 \%$ of that of spruce. In fir, limonene was by far the most abundant compound, and fir scales had a 13 times higher concentration of $\alpha$-pinene than spruce scales. Fir seeds had much higher limonene concentrations than fir scales and than seeds or scales of spruce. Tannin concentrations were higher in cone scales than in seeds, with no differences between the two tree species. This study suggests that high concentrations of limonene might reduce the feeding activity of red squirrels on fir seeds, and that the preferred spruce seeds had much lower monoterpene concentrations. Feeding trials using food items treated with different concentrations of limonene will be carried out to confirm this hypothesis.
\end{abstract}

(c) 2012 Published by Elsevier GmbH on behalf of Deutsche Gesellschaft für Säugetierkunde.

\section{Introduction}

Conifer tree seeds are an important component of the diet of many rodents and the major food resource for arboreal species, such as tree squirrels, in boreal and alpine conifer forests, manmade conifer stands and mixed broadleaf-conifer woods (Abbott and Quink 1970; Wauters and Dhondt 1987; Lurz et al. 2000; Boutin et al. 2006; Wauters et al. 2008; Lobo and Millar 2011). Often, these rodents are not only seed predators, potentially reducing the tree's reproductive output, but also act as seed dispersers, potentially enhancing seedling establishment (reviewed in Theimer 2005; Steele et al. 2005).

\footnotetext{
* Corresponding author. Tel.: +39 0332 421538; fax: +390332421446.

E-mail address: l.wauters@uninsubria.it (L.A. Wauters).
}

Conifers have evolved different mechanisms to reduce seed predation. The marked temporal (annual) variation in seed-crop size, producing large seed-crops at irregular intervals, so-called masting, is widely accepted to have evolved as a predator satiation mechanism in producer-consumer dynamics (Kelly 1994; but see Boutin et al. 2006). Other mechanisms, which tend to result in preferences and/or avoidance of seeds of certain conifers species, or even of individual trees of a given species, are: (i) the amount of protective tissue in cones; (ii) the energy and/or nutrient content of seeds; (iii) the presence and concentration of secondary compounds in seeds or cone scales; and (iv) the patchiness of different tree species affecting time budgets while foraging and thus potential rate of energy-intake (e.g. Farentinos et al. 1981; Benkman 1995; Lewis et al. 2001; Forget et al. 2005; Molinari et al. 2006; Lobo et al. 2009).

Tree squirrels are the most important vertebrate seed predators in boreal and temperate conifer forests and, during periods of seed 
Table 1

Parameters of seed and cone energy, nutrient value (mean \pm SD) and cone morphology of Picea abies and Abies alba.

\begin{tabular}{lll}
\hline Parameter & Picea abies & Abies alba \\
\hline Number of seeds/cone & $232 \pm 59$ & $123 \pm 36$ \\
Total seed mass/cone $(\mathrm{g})$ & $2.563 \pm 0.638$ & $6.888 \pm 1.183$ \\
\% seed/cone fresh mass & 3.4 & 10.3 \\
Seed dry mass (mg/seed) & $9.1 \pm 1.7$ & $43.3 \pm 8.8$ \\
Seed energy-content (kJ/g dry mass) & $24.1 \pm 0.2$ & $27.3 \pm 0.3$ \\
Energy content/cone (kJ) & $51.1 \pm 4.5$ & $145.8 \pm 10.0$ \\
\% protein/seed dry mass & $10.6 \pm 0.5$ & $17.0 \pm 5.7$ \\
\% lipid/seed dry mass & $17.2 \pm 0.6$ & $32.6 \pm 0.2$ \\
\hline
\end{tabular}

shortage, also feed on male flowers, twigs and shoots (Moller 1983; Wauters and Dhondt 1987; Steele et al. 2005). Furthermore, they are known to respond selectively to all of the above mechanisms (Gurnell 1987; Lurz et al. 2005; Steele et al. 2005; Boutin et al. 2006; Molinari et al. 2006).

The main objective of this study was to explore whether differences in plant secondary metabolites (PSMs) between silver fir (Abies alba) and Norway spruce (Picea abies) could be related with the marked feeding preference of Eurasian red squirrels (Sciurus vulgaris) for seeds of the latter species. PSMs are low molecular mass organic compounds with widely varied structures. One recognised function of these molecules is to protect plants against noxious external agents such as herbivores (insects, vertebrates), fungi, bacteria or virus, as biocides against other plants competing for nutrients (water and/or light) or to protect tissues from UVrays or from other physical stressors (Wink 1999). In most plants, PSMs accumulate in organs vulnerable to predators or parasites and important for plants survival and/or reproduction. The largest group of PSM are terpenes (Breitmaier 2006) among which the monoterpenes (compounds which formally derive from metabolic transformation of a $C_{10}$ precursor consisting of 2 isoprene units) are the most common. Many of them, for example the monoterpenes, $\alpha$-pinene and limonene, act as deterrents or even as toxins on invertebrates and on herbivorous or granivorous mammals (Kimball et al. 1998; Ibrahim et al. 2001; Petrakis et al. 2005; Bakkali et al. 2008). Another important class of deterring compounds are tannins (complex, structurally heterogeneous poliphenolic compounds that bind to and cause precipitation of proteins). High levels of some tannins in food-items give raise to several digestive disorders, since they interfere with protein absorption, reduce the action of digestive enzymes, damage the gastrointestinal mucous membrane, or cause loss of endogenous nitrogen (Robbins et al. 1987; Blytt et al. 1988; Shimada and Saitoh 2003). These effects can be highly species-specific for some animals: for example captive held grey squirrels thrived on a pure acorn diet (oak seeds containing high levels of tannins) while captive red squirrels, fed only acorns, die within a few weeks from enteritis (Kenward and Holm 1993).

The Eurasian red squirrel is an opportunistic tree-seed predator which occurs in all alpine and subalpine conifer forest types throughout Europe (Lurz et al. 2005; Mari et al. 2008). It selects seeds of different conifer species and from individual trees within species, based on characteristics that permit to maximise rate of energy-intake and minimise the animal's feeding effort, such as accessibility, a cone structure allowing an easy recovery of seeds, and the correct degree of seed maturation (Moller 1983; Lurz et al. 2000; Molinari et al. 2006). The study of the relationship of treeseed abundance and squirrel population dynamics (Wauters et al. 2008) and space- and habitat use in mixed Norway spruce (Picea abies) - silver fir (Abies alba) forests (Di Pierro et al. 2011), indicate that squirrels feed only rarely on silver fir seeds. Of all alpine conifers, fir has the highest energy-content per cone (Table 1) and the highest ratio of seed/cone mass, hence the lowest amount of protective tissue (Table 1, from Salmaso et al. 2009). Thus, if foraging would be determined mainly by (i) rate of energy-intake, (ii) cone morphology, in particular the reduced amount of protective tissue (Molinari et al. 2006), or (iii) temporal availability of the food source, red squirrels should strongly select fir seeds between mid August and mid October, when they are available in the tree canopy. However, squirrels prefer Norway spruce over fir seeds in all seasons and years and fir seed consumption is limited, occurring to some extent only in years with spruce seed-crop failure (Di Pierro et al. 2011). Since previous studies on squirrel food choice have demonstrated that tannins and terpenes contained in seeds and/or cone scales of some tree species induce animals to reduce consumption of these food items, we have considered the hypothesis that avoidance of fir seeds is caused by higher ratio of some PSMs on dry mass or by higher concentrations of specific PSM(s) in silver fir seeds and/or cones. Although the protective tissue of the cones (scales) is not ingested, bad taste or high resin content of scales might induce squirrels to avoid manipulating cones. In this article we report data on the presence and the concentration of several terpenes in the fresh seeds and cone scales of Picea abies and Abies alba collected in our study areas in the Central Italian Alps and on the protein precipitation activity of contained tannins.

\section{Material and methods}

\section{Field sample collection and transport}

In September 2006 we collected cones with mature seeds from spruces and fir-trees in three sites in the Central Alps, Lombary, Italy. Sites were part of continuous mixed alpine and subalpine conifer forests. Fir seeds were collected in Valle di Albaredo, $\left(46^{\circ} 04^{\prime} 42^{\prime \prime} \mathrm{N}, 9^{\circ} 35^{\prime} 51^{\prime \prime} \mathrm{E}, 1310 \mathrm{~m}\right.$ a.s.l.), spruce seeds in Valfurva (locality. S.Nicolò, $46^{\circ} 27^{\prime} 36^{\prime \prime} \mathrm{N}, 10^{\circ} 24^{\prime} 50^{\prime \prime} \mathrm{E}, 1380 \mathrm{~m}$ a.s.l.) and in Valdisotto (locality Bormio 2000, 46 $26^{\prime} 47^{\prime \prime} \mathrm{N}, 10^{\circ} 23^{\prime} 30^{\prime \prime} \mathrm{E}, 1970 \mathrm{~m}$ a.s.l.).

Spruce cones were cut from lower branches, using a 5-m extension pole with a clipper attached at the end, from trees with diameter at breast height $(\mathrm{DBH})>30 \mathrm{~cm}$. Fir cones, located only in the top of the canopy, were taken from freshly cut trees $(\mathrm{DBH}>30 \mathrm{~cm})$. In both cases, one or two cones were taken per tree, and cones were cut leaving $2-3 \mathrm{~cm}$ of branch attached to avoid oleoresin leaking from the cone. To minimise evaporative loss of volatile terpenes between collection and arrival in the laboratory, sampled cones were closed into air-tight glass containers and immediately refrigerated by storing them in a cool bag filled with ice bricks (temp $<0{ }^{\circ} \mathrm{C}$ ). At the end of samples collection the cones were transported to the lab and stored at $-20^{\circ} \mathrm{C}$ until processing.

\section{Sample preparation}

The extraction of terpenes and of tannins was performed on separate aliquots of ground cone material. From each frozen cone, scales and seeds were manually separated and ground with an electric coffee grinder, adding dry ice into the grinding vessel to keep the sample frozen during this heat-generating process. Between 80 and $100 \%$ of seeds were extracted from spruce and $20-30 \%$ from fir, respectively. Cone scales were taken from the basal third of the cone, a region where variation in the composition of terpenes is reported smaller than in the apical part (Čermák 1987).

\section{Terpene extraction and analysis}

The terpene fraction was extracted by stirring a specimen of $1.000 \pm 0.001 \mathrm{~g}$ of ground seeds or scales in $10 \mathrm{ml}$ of cyclohexane (PESTANAL ${ }^{\circledR}$, Fluka) containing a known amount of octafluoronaphthalene (OFN, $\mathrm{C}_{10} \mathrm{~F}_{8} ; 88,8 \mathrm{mg} / \mathrm{l}$ ) as internal standard for $24 \mathrm{~h}$ at 
room temperature. The mixture was then transferred in a $15 \mathrm{ml}$ Falcon tube and centrifuged (Eppendorf AG, model 5804) at $4000 \mathrm{rpm}$ for $10 \mathrm{~min}$ at $15^{\circ} \mathrm{C}$. At the end of this step, the surnatant solvent was siphoned off and stored in a freezer at $-20^{\circ} \mathrm{C}$ until analyses. A $1 \mathrm{ml}$ portion was transferred with a syringe in a crown capped $2 \mathrm{ml}$ vial and used for gas-chromatography-mass-spectrometry (GC/MS) analysis while another $1 \mathrm{ml}$ portion was transferred to a previously weighted $( \pm 0.1 \mathrm{mg})$ glass vial. From this second vial, the solvent was evaporated to dryness under a gentle nitrogen stream until the residue showed a constant weight, thus obtaining the total mass of organic compounds present in the cyclohexane extracts.

The cyclohexane extracts were analysed by gaschromatography-electron ionisation mass-spectrometry (GC/EI-MS) in an Agilent HP5972 MSD instrument. Separation was accomplished on a trifluoropropyl methyl polysiloxane column (RESTEK, Bellefonte, PA, USA, Rtx ${ }^{\circledR}-200$ MS $30 \mathrm{~m} \times 0.25 \mathrm{~mm}$, film thickness $0.1 \mathrm{~mm}$ ) with helium as carrier gas at a constant velocity of $10 \mathrm{~m} / \mathrm{s}$. Samples $(1 \mu \mathrm{L})$ were injected into a split/splitless injector at a temperature of $300^{\circ} \mathrm{C}$. A multilinear temperature programme was employed, starting with a $10 \mathrm{~min}$ isothermal at $50^{\circ} \mathrm{C}$, followed by a $5^{\circ} \mathrm{C} / \mathrm{min}$ ramp to $270^{\circ} \mathrm{C}$, then a final $2 \mathrm{~min}$ isotherm at $290^{\circ} \mathrm{C}$, for a total duration of the run of $60 \mathrm{~min}$. Solvent was vented for $50 \mathrm{~s}$ and data capture ( $0.8 \mathrm{~s}$ per scan, from 45 to $650 \mathrm{Th})$ was started $5 \mathrm{~min}$ after injection.

Following this procedure, four types of samples were analysed: (a) silver fir seeds (SFSe); (b) silver fir scales (SFSc); (c) Norway spruce seeds (NSSe) and (d) Norway spruce scales (NSSc). To take into account the natural variability of content in the material, nine specimen (each from a different cone) of each sample type were injected for a total of 36 GC-MS runs. To discriminate compounds derived from the analysed samples from those carried on during the extraction procedure and possibly deriving from sample handling (manual cone opening and grinding), from glassware, from solvents and from other extraneous sources, a procedure blank was also prepared with each extraction run and analysed.

To identify the compounds in the extracts and to measure their levels even in the absence of analytical standards, the following parameters were evaluated for each chromatographic peak and calculated from the analytical data:

(1) The elution time and the total ion current (TIC) area of each chromatographic peak, as yielded by the instrument's software;

(2) the relative retention time (RRT) of each analyte, calculated as the elution time of the analyte/the elution time of OFN (both measured in min:s);

(3) the percent abundance of each analyte, calculated as fraction of all chromatographic peak areas, except that of the IS, summing up $100 \%$;

(4) the mass abundance of each analyte peak, expressed as OFN equivalents and calculated as the ratio of analyte peak to OFN (IS) peak area (both measured as as TIC) and referred to the 10$\mathrm{ml}$ volume of cyclohexane extract ( $\mathrm{mg} \mathrm{OFN}_{\text {eq }} / \mathrm{g}$ plant material);

(5) the normalised mass abundance of each analyte (TICn), calculated as the ratio of the mass abundance of each analyte calculated as in (4) and referred to the dry mass of cyclohexane-extractable material obtained from a $1000 \mathrm{~g}$ sample of pulverised plant material.

Identification of compounds in the GC trace of the analysis was accomplished by software comparison of the peak-averaged, background-subtracted EI mass spectra obtained from each identified peak to those of the MS library. Whenever possible, confirmation or selection among alternatives was obtained by human inspection of the spectra, especially to check the occurrence of low-abundance molecular peaks. In most cases the possibility of multiple isomers and stereoisomers yielding undistinguishable
$70 \mathrm{eV}$ EI mass spectra precluded the accurate assignment of compound identity on the basis of the obtained information.

\section{Tannin extraction and analysis}

Based on the principal characteristic of tannins, which are able to bind to and to precipitate proteins as insoluble complex materials, and in accordance with earlier work on squirrels (Lurz et al. 2000), we used the method described by Hagerman and Butler (1979). This method quantifies the content of condensed and hydrolysable tannins in plant materials by measuring the ability of the extracts to bind to and to precipitate bovine serum-albumin (BSA). Tannin concentration, is calculated by interpolation on a calibration curve obtained from a tannin-acid solution prepared at known concentrations (from 0.1 to $2.0 \mathrm{mg} / \mathrm{ml}$ ) and the absorbance of a reagent blank solution of $\mathrm{FeCl}_{3}$ in SDS/TEA. Three determinations were performed on separate aliquots of each type of sample (seeds or cone-scales of spruce or fir).

\section{Statistical analyses}

A General Linear Model (GLM) was used to explore variation in relative concentration (TICn) for each of the seven most important monoterpenes as dependent variable (see Terpenes extraction and analysis for details), using species (spruce or fir) and material (seeds or scales) as fixed effects and testing for a species by material interaction. When the interaction was significant, Differences of Least Squares Means (DLSM) were used to explore pair-wise differences. Similarly, a GLM was used to explore variation in tannine concentration (dependent variable) using species (spruce or fir) and material (seeds or scales) as fixed effects and testing for a species by material interaction.

\section{Results}

Cyclohexane-extractable material (CHX) amounted to $2 \%$ of the total mass of seed material and to $0.3 \%$ of scales material, with little difference between fir and spruce. The cyclohexane extract from seeds and scales of both fir and spruce contained a large number of compounds (at least 290 chromatographically separated chemical entities), about two-thirds of which could be at least tentatively identified on the basis of their mass spectra. As an example, Fig. 1 shows one representative example of the complex chromatographic trace of the GC-MS separation of each sample type (silver fir seeds, spruce seeds, silver fir cones, spruce cones). Complete analytical results, including recorded mass spectra and library comparison is collected in the Supplementary Material.

Due to lack of analytical standards for most of the compounds, a semi-quantitative evaluation of the amount of the different components of the extracts was accomplished by employing $1,2,3,4,7,8,9,10$-octafluoro-naphtalene (OFN) as the internal standard throughout sample preparation and analysis. This particular compound was selected since it is at all extraneous to any natural mixture or as an environmental contaminant and is mostly employed in analytical laboratories to check the performance of GC-MS systems according to manufacturers' specifications. Therefore OFN can be employed both to lock the relative retention time (RRT) of chromatographic peaks and to relate the abundance of compounds to that of OFN even in the absence of a systematic compound-specific analytical calibration. The semiquantitative side of this procedure implicitly accepts that absolute values (expressed as micrograms $\mathrm{OFN}_{\mathrm{eq}} / \mathrm{mL}$ or as milligrams $\mathrm{OFN}_{\mathrm{eq}} / \mathrm{g}$ of processed material) tend to be unreliable, especially for samples with a higher proportion of volatile terpenes, such as limonene, since these compounds are usually more highly responsive to EIGC-MS than OFN (i.e., they yield much more intense peaks than 

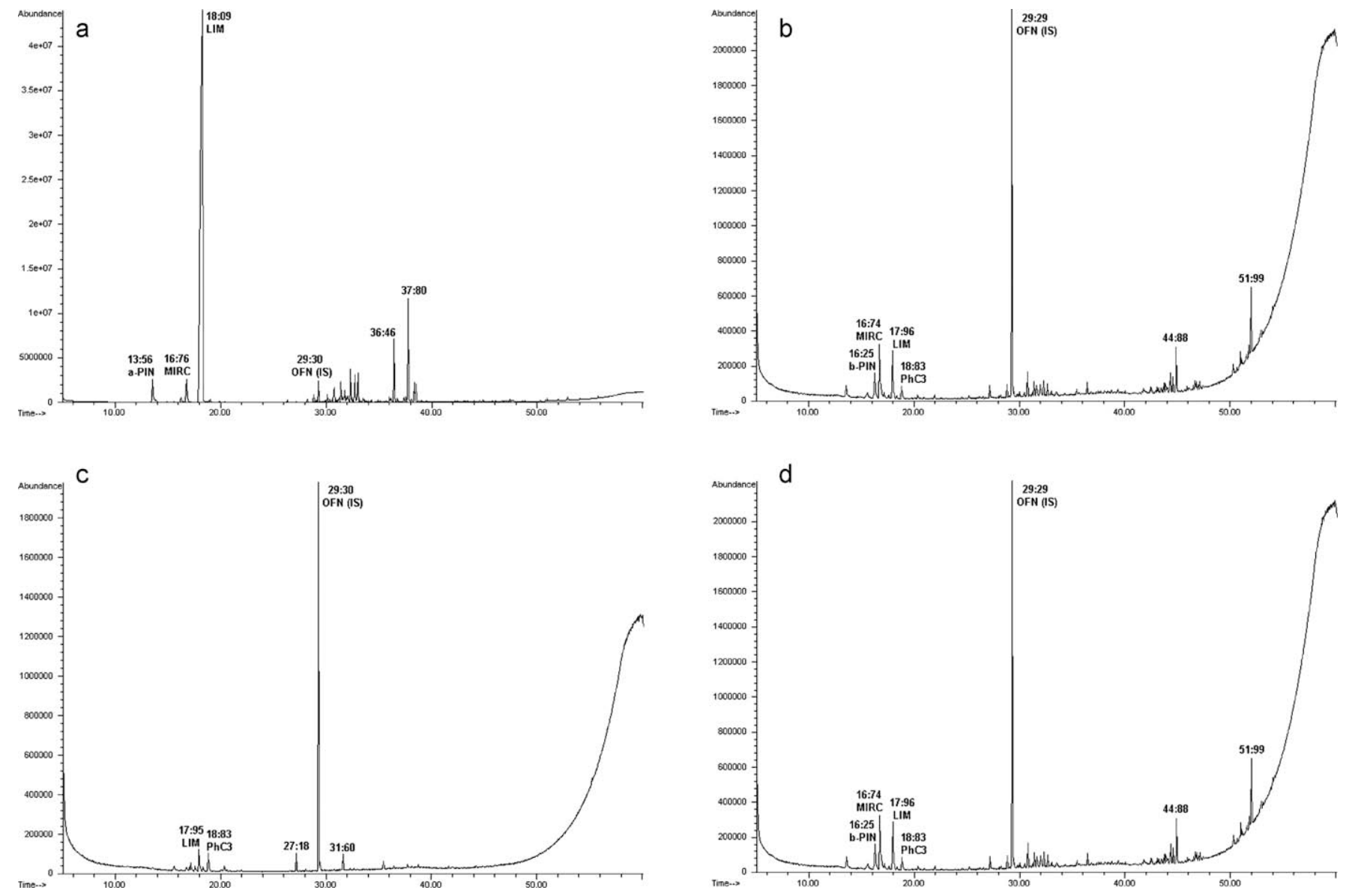

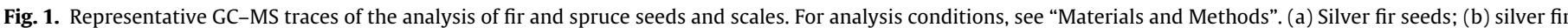
scales; (c) Norway spruce seeds; (d) Norway spruce scales.

OFN on a mass basis). According to this calculation, the fraction of GC-amenable substances in the cyclohexane extract (i.e., the fraction of semi-volatile, non-resinous material) can be estimated, as reported in Table 2 .

The seeds of silver fir are the richest in CHX-extractable GCeluting organic materials, while both seeds and scales of spruce contain very little terpenoids (Table 2). As evaluated from the comparison of the mass of GC-eluted materials (although expressed as mg of OFN equivalents) to the mass of CHX-extracted material, which often results in $>100 \%$ mass ratios, it is likely that little high-mass polymerised resin, unamenable to GC analysis, is either present as such in the plant materials or is artificially formed during sample storage and extraction.

Of the nearly 300 separated chemical entities, only limonene, pinene $\alpha$-and $\beta$-isomers and myrcene have been identified in all 36 examined samples and their abundance account for $80 \%$ or more of all cyclohexane-extractable GC-eluting organic materials of fir and for less than $50 \%$ of that of spruce (average all 36 samples $>75 \%$ ).

Besides from the large number of natural products, also minute traces of ubiquitary lipophilic environmental contaminants, such as some isomeric C-3 and C-4 alkylbenzene isomers and a few polycyclic aromatic hydrocarbons were detected in the samples, possibly making this plant material an unexpectedly convenient matrix to study bioaccumulation of persistent organic pollutants (POPs, e.g. Schröter-Kermani et al. 2006).

Table 3 lists the abundance (mean \pm DS; interval), expressed as $\mathrm{mg}$ of OFN equivalents per $\mathrm{g}$ of cyclohexane-extractable material, of the seven most represented compounds in each sample type. As apparent, in fir one individual component, limonene, is by far the most abundant compound ( $>75 \%$ by weight in seeds and $34 \%$ in scales), while in spruce cyclohexane-extractable matter is distributed over a wider range of compounds, pinene $\alpha$ - and $\beta$-isomers and caryophyllene isomers being more abundant than limonene.

In fir scales, $\alpha$-pinene is the most abundant, with a concentration 13 times higher than in spruce scales. In spruce seeds the content of $\alpha$-pinene is very low while in fir seeds is comparable with the amount found in the scales. In spruce scales, $\beta$-pinene has the highest concentration, being only slightly lower the concentration in both seeds and scales of fir. Myrcene was found in larger concentration in fir seeds and in spruce scales. Several isomers of

Table 2

Results of chemical analyses of cyclohexane (CHX) extracts of Abies alba and Picea abies cones.

\begin{tabular}{|c|c|c|c|c|}
\hline \multirow[t]{2}{*}{ Plant material $(N)$} & \multicolumn{2}{|c|}{ Dry weight of CHX extract (mg/g material) } & \multicolumn{2}{|c|}{$\mathrm{mg} \mathrm{OFN}_{\mathrm{EQ}} / \mathrm{g}$ material } \\
\hline & Mean \pm DS & Min-max & Mean \pm DS & ( $\mathrm{mg} / \mathrm{g}$ material) \\
\hline A. alba - seeds (9) & $24.5 \pm 2.6$ & $18.9-28.0$ & $340.9 \pm 178.9$ & $73.0-600.9$ \\
\hline A. alba - scales (9) & $3.6 \pm 2.0$ & $1.7-7.6$ & $11.5 \pm 6.4$ & $2.1-22.2$ \\
\hline P. abies - seeds (9) & $20.7 \pm 5.9$ & $14.3-32.5$ & $8.3 \pm 11.2$ & $0.04-33.4$ \\
\hline P. abies - scales (9) & $3.4 \pm 2.2$ & $1.4-7.4$ & $4.9 \pm 4.9$ & $0.7-16.6$ \\
\hline
\end{tabular}


Table 3

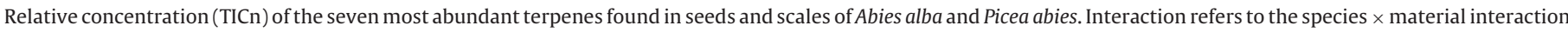
in the GLM model.

\begin{tabular}{|c|c|c|c|c|c|c|c|}
\hline \multirow[t]{2}{*}{ Terpene } & \multicolumn{2}{|l|}{ Abies alba } & \multicolumn{2}{|l|}{ Picea abies } & \multicolumn{3}{|c|}{ GLM statistics } \\
\hline & Seeds & Scales & Seeds & Scales & Species & Material & Interaction \\
\hline Limonene & $\begin{array}{l}12.27 \pm 2.22 \\
(1.91-19.77)\end{array}$ & $\begin{array}{l}1.292 \pm 0.384 \\
(0.250-2.830)\end{array}$ & $\begin{array}{l}0.026 \pm 0.012 \\
(0.001-0.117)\end{array}$ & $\begin{array}{l}0.092 \pm 0.014 \\
(0.040-0.156)\end{array}$ & $\begin{array}{l}F=36.7 \\
P<0.001\end{array}$ & $\begin{array}{l}F=23.4 \\
P<0.001\end{array}$ & $\begin{array}{l}F=23.9 \\
P<0.001\end{array}$ \\
\hline$\alpha$-Pinene & $\begin{array}{l}1.09 \pm 0.33 \\
(0.13-3.33)\end{array}$ & $\begin{array}{l}1.674 \pm 0.325 \\
(0.191-3.022)\end{array}$ & $\begin{array}{l}0.031 \pm 0.015 \\
(0.001-0.125)\end{array}$ & $\begin{array}{l}0.122 \pm 0.026 \\
(0.018-0.236)\end{array}$ & $\begin{array}{l}F=31.4 \\
P<0.001\end{array}$ & $\begin{array}{l}F=2.07 \\
P=0.16\end{array}$ & $\begin{array}{l}F=1.11 \\
P=0.30\end{array}$ \\
\hline$\beta$-Pinene & $\begin{array}{l}0.153 \pm 0.038 \\
(0.026-0.393)\end{array}$ & $\begin{array}{l}0.228 \pm 0.042 \\
(0.025-0.397)\end{array}$ & $\begin{array}{l}0.092 \pm 0.045 \\
(\operatorname{tr}-0.392)\end{array}$ & $\begin{array}{l}0.281 \pm 0.061 \\
(0.055-0.540)\end{array}$ & $\begin{array}{l}F=0.01 \\
P=0.93\end{array}$ & $\begin{array}{l}F=7.67 \\
P=0.009\end{array}$ & $\begin{array}{l}F=1.45 \\
P=0.24\end{array}$ \\
\hline Myrcene & $\begin{array}{l}0.225 \pm 0.033 \\
(0.063-0.337)\end{array}$ & $\begin{array}{l}0.029 \pm 0.006 \\
(0.008-0.052)\end{array}$ & $\begin{array}{l}0.043 \pm 0.016 \\
(\operatorname{tr}-0.137)\end{array}$ & $\begin{array}{l}0.122 \pm 0.026 \\
(0.008-0.250)\end{array}$ & $\begin{array}{l}F=3.93 \\
P=0.06\end{array}$ & $\begin{array}{l}F=6.68 \\
P=0.015\end{array}$ & $\begin{array}{l}F=37.1 \\
P<0.001\end{array}$ \\
\hline Dehydroabietane & $\begin{array}{l}0.003 \pm 0.001 \\
(0-0.007)\end{array}$ & $\begin{array}{l}0.025 \pm 0.008 \\
(0-0.057)\end{array}$ & $\begin{array}{l}0.024 \pm 0.011 \\
(0-0.028)\end{array}$ & $\begin{array}{l}0.020 \pm 0.010 \\
(0-0.078)\end{array}$ & $\begin{array}{l}F=0.88 \\
P=0.35\end{array}$ & $\begin{array}{l}F=1.23 \\
P=0.28\end{array}$ & $\begin{array}{l}F=2.24 \\
P=0.14\end{array}$ \\
\hline $\begin{array}{l}\text { Caryophyllene } \\
\text { trans (isomer 1) }\end{array}$ & $0.00 \pm 0.00$ & $\begin{array}{l}0.147 \pm 0.046 \\
(0-0.405)\end{array}$ & $\begin{array}{l}0.087 \pm 0.052 \\
(0-0.482)\end{array}$ & $\begin{array}{l}0.119 \pm 0.043 \\
(0-0.350)\end{array}$ & $\begin{array}{l}F=0.52 \\
P=0.48\end{array}$ & $\begin{array}{l}F=4.83 \\
P=0.035\end{array}$ & $\begin{array}{l}F=1.99 \\
P=0.17\end{array}$ \\
\hline $\begin{array}{l}\text { Caryophyllene } \\
\text { trans (isomer 2) }\end{array}$ & $\begin{array}{l}0.009 \pm 0.003 \\
(0-0.011)\end{array}$ & $0.00 \pm 0.00$ & $\begin{array}{l}0.032 \pm 0.025 \\
(0-0.227)\end{array}$ & $\begin{array}{l}0.050 \pm 0.039 \\
(0-0.347)\end{array}$ & $\begin{array}{l}F=2.56 \\
P=0.12\end{array}$ & $\begin{array}{l}F=0.05 \\
P=0.83\end{array}$ & $\begin{array}{l}F=0.34 \\
P=0.56\end{array}$ \\
\hline
\end{tabular}

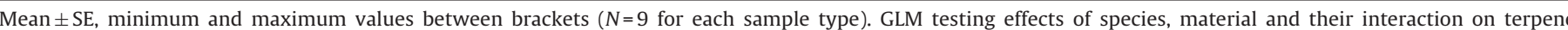
concentrations ( $\mathrm{df}=1,32$ in all cases).

the sesquiterpene hydrocarbon $\mathrm{C}_{15} \mathrm{H}_{24}$ (MW 204) are detected in the GC-MS analyses but an accurate definition of the individual isomers is precluded by the close similarity of EI spectra and by the low intensity of most chromatographic peaks. One of the most abundant among such components is identified by library comparison as caryophyllene and is present in two chromatographically separate forms, of which the (earlier eluting) isomer 1 is present in fir scales and (later-eluting) isomer 2 in fir seeds (Table 3 ).

Fir seeds show a higher concentration of limonene with respect to that in fir scales, in spruce seeds and in spruce scales (Table 3, DLSM all $P<0.001$ ). There is no difference in limonene concentration between spruce scales and seeds (DLSM $P=0.97$ ) or between scales of fir and spruce (DLSM $P=0.42$ ). Only tree species had an effect on concentration of $\alpha$-pinene, with both seeds and scales of fir having higher concentrations than of spruce (Table 3, DLSM seeds $P=0.003$, scales $P<0.001$ ). Overall, cone scales had higher concentrations of $\beta$-pinene than seeds (Table 3 ), however the difference was significant only in spruce (DLSM spruce $P=0.008$, fir $P=0.28$ ). Patterns of myrcene concentrations differed between species (Table 3 , species by material interaction): in fir, concentrations were higher in seeds than scales (DLSM, $P<0.001$ ), while the opposite occurred in spruce (DLSM $P=0.02$ ). Consequently, myrcene concentrations were higher in spruce than fir scales (DLSM $P=0.007$ ). Finally, isomer 1 of caryophillene was more abundant in scales than seeds (Table 3 ).

Mean $( \pm \mathrm{SE})$ tannin concentration of spruce was $0.081 \pm 0.040 \mathrm{mg} / \mathrm{ml}$ and $0.475 \pm 0.098 \mathrm{mg} / \mathrm{ml}$ for seeds and scales respectively. For fir it was $0.042 \pm 0.013 \mathrm{mg} / \mathrm{ml}$ and $0.398 \pm 0.097 \mathrm{mg} / \mathrm{ml}$ for seeds and scales respectively. Scales had higher tannin concentrations than seeds, independent of tree species (material $F_{1,8}=40.6, P=0.0002$; species $\times$ material interaction $F_{1,8}=0.10, P=0.76$ ). There was no difference between spruce and fir in tannin concentration (species $F_{1,8}=0.97, P=0.35$ ).

\section{Discussion}

GC-MS revealed at least 290 chromatographically separated chemical entities contained in seeds and/or cone scales of silver fir and Norway spruce. The seeds of silver fir were the richest in cyclohexane-extractable GC-eluting organic materials, while both seeds and scales of spruce contained much lower amounts of terpenoids. Despite this diversity in chemical composition of the extracts, four compounds, limonene, pinene $\alpha$ - and $\beta$-isomers and myrcene, were identified in all samples, and their levels accounted for $80 \%$ or more of all cyclohexane-extractable GC-eluting organic materials of fir and for nearly $50 \%$ of that of spruce. Moreover since they all differ in seeds and/or cones between spruce and fir, they could act as chemical feeding deterrents for squirrels, or simply cause bad taste (e.g. Ruxton and Kennedy 2006). Deterring effects of terpenes have been documented in detail for the Pinus ponderosa-Sciurus aberti system. This North-American squirrel species, closely linked with Ponderosa pine forests, selects trees with lower concentrations of monoterpenes, feeding mainly on the bark of small twigs during winter rather than on random trees, thus reducing the fitness of individual trees and hence exercising strong selective pressure on this species towards strains with a higher content of deterring chemicals (Farentinos et al. 1981; Snyder 1992; Snyder and Linhart 1994; Latta et al. 2000). We know of no previous studies that have looked at differences in terpenes between seeds of different conifer species more or less preferred by Eurasian red squirrels.

\section{Fir versus spruce}

Several studies on food selection of small rodents showed that seeds of the genus Picea are preferred over Abies seeds (Schreiner et al. 2000; Lobo et al. 2009; Lobo and Millar 2011).

Our previous work, including observations of feeding behaviour (Wauters et al. 2008; Di Pierro et al. 2011), showed that also red squirrels prefer spruce and avoid fir seeds.

Since limonene is by far the most abundant compound ( $>75 \%$ by weight in seeds and 34\% in scales) in fir, we believe it is the most likely terpenoid to act as a feeding deterrent. We are aware that our results are only correlative and we cannot conclude that limonene is the key feeding deterrent for red squirrels in the Alps. Therefore, we will carry out feeding experiments with captive red squirrels from subalpine forests, using both seeds, cones and artificial diets with varying limonene concentrations to verify our hypothesis. Similar high levels of limonene in fir seeds were found in stands in Central Europe (Čermák 1987) suggesting it is a characteristic typical for the species and relatively independent from geographic location and forest characteristics. There was a 10 -fold higher concentration of limonene in seeds than in scales of silver fir, but a 500 times higher concentration in fir than spruce seeds, suggesting that allocation of limonene in the seeds, and not in the protective (scale) tissue, serves to reduce fir seed predation.

Also $\alpha$-pinene concentration was higher in fir than in spruce seeds and could act as a second deterrent. This does not mean that 
the trees do not allocate terpenoids in scales as a strategy to make manipulation of cones, in particular scale removal by tearing or cutting using the incisors (Rima et al. 2007), more difficult. In fact, also scales contained high concentrations of terpenoids and $\alpha$-pinene content was 13 times higher in fir than in spruce scales. Moreover, cone scales had higher concentrations of $\beta$-pinene than seeds, although this difference was significant only in spruce.

\section{Limonene and bad taste?}

Secondary compounds, in our case terpenoids, can be efficient without being toxic, by having a bad smell or taste (e.g. Ruxton and Kennedy 2006). Both rodents (Weiler et al. 2006) and some birds (McKeegan 2002) appear to use olfaction to detect limonene, which also exhibits a strong oral toxicity and induces marked aversive behaviour in some insect (Ozaki et al. 2003). The natural D-(+)-Rlimonene enantiomer has the typical smell and acid taste of lemon (EPA 1994) and, therefore is likely to produce a bad taste of fir seeds. Although the toxicity of limonene in wild animals such as squirrels has not been reported, detailed studies have been performed in other animal species of common use in toxicology, such as in rats and dogs, in the view of relieving concern over the health hazard of popular limonene-containing food. At very high dose ( $300 \mathrm{mg} / \mathrm{kg}$ body mass/day) limonene is toxic in strains of laboratory rats (Jameson 1990). Extrapolating this to the $330 \mathrm{~g}$ of an adult red squirrel (Wauters et al. 2007) an intake of about $99 \mathrm{mg} /$ day of limonene might be toxic. Based on $75 \%$ of limonene of the $2 \%$ cyclohexane-extractable material of total seed dry mass, we can make a rough estimate of $44-124 \mathrm{mg}$ of limonene in the seeds of one fir cone. Hence consuming all seeds of one or two fir cones per day could result in a limonene intake that could potentially be toxic in the long term.

Several experiments in which preferred food items given to deer species were treated with different concentrations of monoterpenes showed that limonene, $\alpha$-pinene and myrcene, which were also the three most common terpenes in fir seeds in this study, caused deer to avoid the treated food (Elliott and Loudon 1987; Vourc'h et al. 2002), confirming their effectiveness as deterrents. Indirect evidence that limonene acts as a feeding deterrent was also found for two other rodents. North American porcupines (Erethizon dorsatum), targetted the phloem of ponderosa pine (Pinus ponderosa) trees which had lower levels of limonene in the xylem oleoresin than matched nontarget trees, and there was a significant negative association between levels of limonene and the amount of phloem removed from individual trees (Snyder and Linhart 1997). In a study on meadow voles (Microtus pennsylvanicus) during a population peak, undamaged seedlings of white spruce (Picea glauca) and white pine (Pinus strobus) contained myrcene and higher levels of limonene than severely damaged seedlings of Norway spruce and Norway pine (Pinus resinosa) (Bucyanayandi et al. 1990).

\section{Terpenoids in spruce}

Both limonene and $\alpha$-pinene occurred in low concentrations in spruce seeds. In contrast, $\beta$-pinene had the highest concentration in spruce scales, which was similar to the concentrations found in fir scales and seeds. Also myrcene was found in larger concentration in spruce scales than seeds, and its content was higher in spruce than in fir scales. Hence, spruce seemed to collocate terpenoids in scales rather than seeds. This seems also the case in another subalpine conifer, whose seeds are strongly preferred by squirrels, the Arolla pine (Pinus cembra, Dormont et al. 1998). Spruce and Arolla pine have cones that during and in the first months after seed maturation are resinous and thus sticky, which must make cone-handling by seed predators difficult.

\section{The role of tannins}

The role of tannin concentration on food choice of tree squirrels is reported mainly for large deciduous nuts (e.g. Short 1976; Smallwood and Peters 1986; Kenward and Holm 1993; Steele et al. 1993, 2005). We found no differences in tannin concentration between fir and spruce seeds (or scales) indicating that tannin is not responsible for squirrels selecting spruce and avoiding fir seeds. Low concentrations in both spruce and fir seeds are in agreement with those reported in seeds of other conifers such as Pinus sylvestris and Pinus contorta; in contrast, nuts of many deciduous trees, e.g. acorns and walnuts, have typically high tannin concentrations (Lurz et al. 2000; Bertolino and Wauters unpubl. data). It remains uncertain why scales of spruce and fir have relatively high concentrations of tannin. Tannin in scales cannot be the result of a plant anti-predator strategy against vertebrates, since tannin must be ingested to reduce protein absorption or cause other negative effects (Shimada and Saitoh 2003). Nevertheless, tannin in scales might serve as protection against seedor cone-feeding insects whose larvae have to penetrate inside the cone, such as Cydia strobilella (Lepidoptera, Tortricidae) and Resseliella piceae (Diptera, Cecidomyiidae), the most important insect seed-predators of spruce and fir respectively (Skrzypczýnska 1981, 1982).

We conclude that our data suggest that high concentrations of monoterpenes, in particular limonene, in fir seeds act as feeding deterrents and seem to strongly reduce the feeding activity of red squirrels on fir seeds. Whether limonene concentration is the key-factor causing fir seeds to be avoided will have to be further tested with feeding trials (e.g. Vourc'h et al. 2002). Squirrels prefer spruce seeds, which have low monoterpene concentrations, from late summer to the next spring, when cones open and seeds are dispersed. The short period of fir seed availability in closed cones in the tree canopy, could potentially produce strong selective pressure on squirrel feeding (and cone caching) behaviour and result in a evolutionary arms race between conifers and squirrels (e.g. Benkman 1995; Mezquida and Benkman 2005). In the case of silver fir, efficient protection against seed predators by accumulating monoterpenes in seed tissue seems to be the winner's strategy.

\section{Acknowledgements}

We thank Ambrogio Molinari for help with the fieldwork. This study is part of the ASPER project (Alpine Squirrel Population Ecology Research), funded by the province of Sondrio (Servizio Agricoltura, Caccia e Pesca, Settore Risorse Ambientali), and the Parco Regionale delle Orobie Valtellinesi to Istituto Oikos NGO, Milan. Additional financial support was given by MIUR (Ministero dell'Istruzione, dell'Università della Ricerca, Project COFIN 2003, Number 2003053710-006) to Insubria University of Varese. This is paper no. 23 of the ASPER project.

\section{Appendix A. Supplementary data}

Supplementary data associated with this article can be found, in the online version, at doi:10.1016/j.mambio.2012.01.003.

\section{References}

Abbott, H.G., Quink, T.F., 1970. Ecology of eastern white pine seed caches made by small mammals. Ecology 51, 271-278.

Bakkali, F., Averbeck, S., Averbeck, D., Idaomar, M., 2008. Biological effects of essential oils: a review. Food Chem. Toxicol. 46, 446-475.

Benkman, C.W., 1995. The impact of tree squirrels (Tamiasciurus) on limber pine seed dispersal adaptations. Evolution 49, 585-592.

Blytt, H.J., Guscar, T.K., Butler, L.G., 1988. Antinutritional effects and ecological significance of dietary condensed tannins may not be due to binding and inhibiting digestive enzymes. J. Chem. Ecol. 14, 1455-1465. 
Boutin, S., Wauters, L.A., McAdam, A.G., Humphries, M.M., Tosi, G., Dhondt, A.A. 2006. Anticipatory reproduction and population growth in seed predators. Science $314,1928-1930$.

Breitmaier, E., 2006. Terpenes: Flavors, Fragances, Pharmaca Pherormones. Wiley$\mathrm{VCH}$, Oxford, UK.

Bucyanayandi, J.D., Bergeron, J.-M., Menard, H., 1990. preference of meadow voles (Microtus pennsylvanicus) for conifer seedlings: chemical components and nutritional quality of bark of damaged and undamaged trees. J. Chem. Ecol. 16, 2569-2579.

Čermák, J., 1987. Monoterpene hydrocarbon contents of the resin from the seeds of silver fir (Abies alba Mill.). Trees 1, 94-101.

Di Pierro, E., Ghisla, A., Wauters, L.A., Molinari, A., Martinoli, A., Gurnell, J., Tosi, G., 2011. The effects of seed availability on habitat use by a specialist seed predator. Eur. J. Wildl. Res. 57, 585-595.

Dormont, L., Roques, A., Malosse, C., 1998. Cone and foliage volatiles emitted by Pinus cembra and some related conifer species. Phytochemistry 49, 12691277.

Elliott, S., Loudon, A., 1987. Effects of monoterpene odors on food selection by red deer calves (Cervus elaphus). J. Chem. Ecol. 13, 1343-1349.

EPA, 1994. R.E.D Facts - Limonene. United States Environment Protection Agency, Washington, DC.

Farentinos, R.C., Capretta, P.J., Kepner, R.E., Littlefield, V.M., 1981. Selective herbivory in tassel-eared squirrels: role of monoterpenes in Ponderosa pine chosen as feeding trees. Science 213, 1273-1275.

Forget, P.-M., Lambert, J.E., Hulme, P.E., Vander Wall, S.B., 2005. Seed Fate: Predation, Dispersal and Seedling Establishment. CABI Publishing, CAB International, Wallingford, UK.

Gurnell, J., 1987. The Natural History of Squirrels. Christopher Helm, London.

Hagerman, A.E., Butler, L.G., 1979. Protein precipitation method for the quantitative determination of tannins. J. Agric. Food Chem. 26, 809-812.

Ibrahim, M.A., Kainulainen, P., Aflatuni, A., Tiilikkala, K., Holopainen, J.K., 2001. Insecticidal, repellent, antimicrobial activity and phytotoxicity of essential oils: with special reference to limonene and its suitability for control of insect pests. Agric. Food Sci. Finland 10, 243-259.

Jameson, C.W., 1990. Toxicology and carcinogenesis studies of d-limonene (CAS n 5989-27-5) in F344/N rats and B6C3F1 mice (gavage studies). NTP technical report n. 347, US Dept. of health and human services, USA.

Kelly, D., 1994. The evolutionary ecology of mast seeding. Trends Ecol. Evol. 9, 465-470.

Kenward, R.E., Holm, J.L., 1993. On the replacement of the red squirrel in Britain: a phytotoxic explanation. Proc. R. Lond. Soc. B 251, 187-194.

Kimball, B.A., Nolte, D.L., Engeman, R.M., Johnston, J.J., Stermitz, F.R., 1998. Chemically mediated foraging preference of black bears (Ursus americanus). J. Mammal. $79,448-456$

Latta, R.G., Linhart, Y.B., Lundquist, L., Snyder, M.A., 2000. Patterns of monoterpene variation within individual trees in ponderosa pine. J. Chem. Ecol. 26, 13411357.

Lewis, C.E., Clark, T.W., Derting, T.L., 2001. Food selection by the white-footed mouse (Peromyscus leucopus) on the basis of energy and protein contents. Can. J. Zool. 79, 562-568.

Lobo, N., Millar, J.S., 2011. The efficacy of conifer seeds as major food resources to deer mice (Permoyscus maniculatus) and southern red-backed voles (Myodes gapperi). Mamm. Biol. 76, 274-284.

Lobo, N., Duong, M., Millar, J.S., 2009. Conifer-seed preferences of small mammals. Can. J. Zool. 87, 773-780.

Lurz, P.W.W., Garson, P.J., Wauters, L.A., 2000. Effects of temporal and spatial variations in food supply on the space and habitat use of red squirrels, Sciurus vulgaris L. J. Zool., Lond. 251, 167-178.

Lurz, P.W.W., Gurnell, J., Magris, L., 2005. Sciurus vulgaris. Mammalian species, vol. 769. American Society of Mammalogists, USA.

Mari, V., Martini, S., Romeo, C., Molinari, A., Martinoli, S., Tosi, G., Wauters, L.A., 2008. Record litter size in the eurasian red squirrel (Sciurus vulgaris). Hystrix: Ital. J. Mamm. 19, 61-65.

McKeegan, D.E.F., 2002. Spontaneous and odour evoked activity in single avian olfactory bulb neurones. Brain Res. 929, 48-58.

Mezquida, E.T., Benkman, C.W., 2005. The geographic selection mosaic for squirrels, crossbills and Aleppo pine. J. Evol. Biol. 18, 348-357.

Molinari, A., Wauters, L.A., Airoldi, G., Cerinotti, F., Martinoli, A., Tosi, G., 2006. Cone selection by Eurasian red squirrels in mixed conifer forests in the Italian Alps. Acta Oecol. 30, 1-10.

Moller, H., 1983. Foods and foraging behaviour of red (Sciurus vulgaris) and grey (S. carolinensis) squirrels. Mamm. Rev. 13, 81-98.
Ozaki, M., Takahara, T., Kawashara, Y., Wada-Katsumata, A., Seno, K., Amakawa, T. Yamaoka, R., Nakamura, T., 2003. Perception of noxious compounds by contact chemoreceptors of the blowfly Phormia regina: putative role of an odorantbinding protein. Chem. Senses 28, 349-359.

Petrakis, P.V., Roussis, V., Papadimitriou, D., Vagia, C., Tsitsimpikou, C., 2005. The effect of terpenoid extracts from 15 pine species on the feeding behavioural sequence of the late instars of the pine processionary caterpillar Thaumetopoed pityocampa. Behav. Process. 69, 303-322.

Rima, P., Aloise, G., Cagnin, M., Wauters, L.A., 2007. The use of species-specific cone remains of sympatric arboreal rodents to monitor their distribution. It. J. Zool. 74, 289-296.

Robbins, C.T., Hanley, T.A., Hagerman, A.E., Hjeljord, O., Baker, D.L., Schwartz, C.C., Mautz, W.W., 1987. Role of tannins in defending plants against ruminants: reduction in protein availability. Ecology 68, 98-107.

Ruxton, G.D., Kennedy, M.W., 2006. Peppers and poisons: the evolutionary ecology of bad taste. J. Anim. Ecol. 75, 1224-1226.

Salmaso, F., Molinari, A., Di Pierro, E., Ghisla, A., Martinoli, A., Preatoni, D., Cerabolini, B., Tosi, G., Bertolino, S., Wauters, L.A., 2009. Estimating and comparing food availability for tree-seed predators in typical pulsed-resource systems: alpine conifer forest. Plant Biosyst. 143, 258-267.

Schreiner, M., Bauer, E., Kollmann, J., 2000. Reducing predation of conifer seeds by clear-cutting Rubus fruticosus agg. in two montane forest stands. Forest Ecol. Manage. 126, 281-290.

Schröter-Kermani, C., Kreft, D., Schilling, B., Herrchen, M., Wagner, G., 2006. Polycyclic aromatic hydrocarbons in pine and spruce shoots-temporal trends and spatial distribution. J. Environ. Monit. 8, 806-811.

Shimada, T., Saitoh, T., 2003. Negative effects of acorns on the wood mouse Apodemus speciosus. Pop. Ecol. 45, 7-17.

Short, H.L., 1976. Composition and squirrel use of acorns of black and white oak groups. J. Wildl. Manage. 40, 479-483.

Skrzypczýnska, M., 1981. The entomofauna of the cones of fir (Abies alba) in Poland Mitt. Schweiz. Entomol. Ges. 54, 291-295.

Skrzypczýnska, M., 1982. The entomofauna of the cones of spruce Picea abies (L.) Karst. in Poland. Z. Angew. Entomol. 94, 21-31.

Smallwood, P.D., Peters, D., 1986. Gray squirrels food preferences: the effects of tannin and fat concentrations. Ecology 67, 168-174.

Snyder, M.A., 1992. Selective herbivory by Abert's squirrel mediated by chemica variability in ponderosa pine. Ecology 73, 1730-1741.

Snyder, M.A., Linhart, Y.B., 1994. Nest-site selection by Abert's squirrel: chemical characteristics of nest trees. J. Mammal. 75, 136-141.

Snyder, M.A., Linhart, Y.B., 1997. Porcupine feeding patterns: selectivity by a generalist herbivore? Can. J. Zool. 75, 2107-2111.

Steele, M.A., Knowles, T., Bridle, K., Simms, E.L., 1993. Tannins and partial consumption of acorns: implications for dispersal of oaks by seed predators. Am. Midl. Nat. 130, 229-238.

Steele, M.A., Wauters, L.A., Larsen, K.W., 2005. Selection, predation and dispersal of seeds by tree squirrels in temperate and boreal forests: are tree squirrels keystone granivores? In: Forget, P.-M., Lambert, J.E., Hulme, P.E., Vander Wall, S.B. (Eds.), Seed Fate: Predation, Dispersal and Seedling Establishment. CAB Publishing, CAB International, Wallingford, UK, pp. 205-221.

Theimer, T.C., 2005. Rodent scatterhoarders as conditional mutualists. In: Forget P.M., Lambert, J.E., Hulme, P.E., Vander Wall, S.B. (Eds.), Seed Fate: Predation, Dispersal and Seedling Establishment. CABI Publishing, CAB International, Wallingford, UK, pp. 283-295.

Vourc'h, G., De Garine-Wichactitsky, M., Labbè, A., Rosolowski, D., Martin, J.-L., Fritz, H., 2002. Monoterpene effect on feeding choice by deer. J. Chem. Ecol. 28, 2411-2427.

Wauters, L.A., Dhondt, A.A., 1987. Activity budget and foraging behaviour of the red squirrel (Sciurus vulgaris Linnaeus, 1758) in a coniferous habitat. Z. Säugetierk 52, 341-352.

Wauters, L.A., Vermeulen, M., Van Dongen, S., Bertolino, S., Molinari, A., Tosi, G. Matthysen, E., 2007. Effects of spatio-temporal variation in food supply on red squirrel Sciurus vulgaris body size and body mass and its consequences for some fitness components. Ecography 30, 51-65.

Wauters, L.A., Githiru, M., Bertolino, S., Molinari, A., Tosi, G., Lens, L., 2008. Demography of alpine red squirrel populations in relation to fluctuations in seed crop size. Ecography 31, 104-114.

Weiler, E., Deutsch, S., Apfelbach, R., 2006. Combined behavioral and c-Fos studies elucidate the vital role of sodium for odor detection. Chem. Senses 31 641-647.

Wink, M., 1999. Biochemistry of Plant Secondary Metabolism. Annual Plant Reviews, vol. 2. Sheffield Academic Press, Sheffield, UK. 